\title{
Factors causing mismanagement in public/private contracts: An Indonesian perspective
}

\author{
Norazida Mohamed $^{a^{*}}$, A. Muhtadi Ridwan ${ }^{b}$, Oussama Saoula ${ }^{c}$ and Mustafa Rashid Issa ${ }^{d}$
}

${ }^{a}$ Accounting Research Institute, Universiti Teknologi MARA, Malaysia

${ }^{b}$ Faculty of Economics, State Islamic University Maulana Malik Ibrahim Malang, Indonesia

${ }^{c}$ School of Business Management, College of Business, Universiti Utara Malaysia

06010 Sintok Kedah Malaysia

${ }^{d}$ Department of Law, Ishik University Iraq, Iraq

\section{CH R O N I C L E}

\section{Article history:}

Received: April 14, 2019

Received in revised format: April

262019

Accepted: May 10, 2019

Available online:

May 10, 2019

Keywords:

Contract management

Planning and scheduling

Contractor

Consultant

Indonesia

\section{A B S T R A C T}

\begin{abstract}
The objective of this study is to examine the impact of client, consultant and contractor related factors on mismanagement in public and private contracts in the region of Indonesia. A structural questionnaire is developed for the selected items after detailed investigation of present literature. A final sample of 137 respondents associated with various contracts in the region of Indonesia is collected with demographic details and regression analysis. It is observed that factors like lack of strategy, failure to compile the documentary requirements, poor planning, delay in decision making, financial issues, late payments, difficulty in getting work permits and lack of management expertise are core issues, creating mismanagement in public and private contracts. In consultant related factors, role of inexperienced consultant, poor planning, late of instructions from architects, poor contract management, and poor-quality assurance are the key determinants of mismanagement in contracts. While contractor related factors like poor planning and scheduling, late or improper submission of contract, inadequate site supervision and inspection, poor construction methods, weak leadership, and lack of communication between the parties are the key indicators of mismanagement in contracts. As per significance, this study is found to be a reasonable addition in the present literature from the context of contract management. Originality of the study covers the significant findings for the policy makers in the field of public and private contracts. Study can be reworked in future through better sampling, and addition of more factors related to materials, equipment and labor causing for the poor delivery of the contracts.
\end{abstract}

C 2019 by the authors; licensee Growing Science, Canada

\section{Introduction}

In construction industry, a successful project is observed if the service provider (contractor) is working with full of dignity and completing the project on time as per the defined financial resources (Gardiner, 2005). Such work can ultimately satisfy the customer's needs and requirements with the timely completion strategy (Chan \& Kumaraswamy, 1997; Koushki et al., 2005). To get the success of construction project, it is very much crucial to identify those factors which are directly or indirectly affecting the success or failure of a task. Based on the time duration, budgeting, cash flows, available resources, risk 
$\&$ uncertainty, and deadlines, construction projects have different categories. In overall project management, scheduling factor has a considerable significance which should be observed carefully. If a construction project is not completed on time, investor will face different issues such as financial and nonfinancial losses. Financial losses in the form of excessive cost or loss of raw material occur in the projects because of higher labor charges due to delay. At the same time, non-financial losses indicate poor customer satisfaction, loss of market share for the future projects, poor delivery and negativity about the firm's repute (Aibinu \& Jagboro, 2002; Bordoli \& Baldwin, 1998). Under the situation of increasing competition, business firms are working constantly to gain more and more market share. This theory is implemented in both manufacturing and service industries.

The Government of Indonesia has started various projects for the improvement of country's infrastructures. The construction of New Priok Port, Jakarta was started during the year 2012 and expected to be completed by 2023 (Indonesia Investment, 2018). At second, Mass Rapid Transit or MRT in Jakarta is a significant improvement in infrastructure covering a budget of 1.7 billion US dollar. Under this project two major corridors; north-south and east-west are being constructed. Another significant public sector construction project is Flyover Roads in Jakarta with the budget of 140.8 million US dollars and is known as mega addition in infrastructure (Indonesia Investment, 2018). This study has aimed to identify the effect of consultant related, client related, and contractor related factors causing a mismanagement of both public and private sector construction projects. For this purpose, researchers have targeted the economies of Indonesia. The rest of the study is as follows. Section two indicates the literature context of the topic, section three shows description about the variables, section four explains methods and sample of the study, section five reflects result and discussion and last section concludes the study.

\section{Literature Context}

As per earlier findings, construction industry is known among the risky and complex business categories due to its major role in the development and improvement of infrastructure (Assaf \& Al-Hejji, 2006; Assaf et al., 1995; Navon, 2005; Winch, 2010). In construction projects, it is found that the success of construction projects is based on the idea that project is performed reasonably, quality of work is conducted, and delivery of work is on time with the good productivity rate from the contractor (Frimpong et al., 2003; Nega, 2008). It is observed that all the construction projects are evaluated through the factor of time, cost and delivery. Various authors in the field of project and construction management highlight the core factors which affect the performance of both public and private projects. The approach of questionnaire has been widely applied to analyze the core factors, responsible for the poor performance in construction project. For instance Saka and Ajayi (2010) examined the factors affecting the delay and poor results in construction project in the region of Nigeria. Another study conducted by Ramanathan et al. (2012) highlighted the fact that for poor construction performance, five factors are mainly responsible. These are under the title of poor design or incomplete design by the designer of the project, poor management expertise, various technological and social issues, site-related problems, application of improper tools and techniques. Another study found that lack of resources, leadership skills, material prices and their fluctuations, low level of experience, and application of poor equipment are the main issues in the project site. Wiguna and Scott (2005) analyzed the core factors responsible for the poor construction results. These factors are under the title of poor workmanship, delay in payments to the contractors, defective design, weather conditions and high information. In addition, different studies examined various factors which are related to clients and causing a poor outcome in construction projects (Aibinu \& Odeyinka, 2006; Chan \& Kumaraswamy, 1996; Doloi, Sawhney, Iyer, \& Rentala, 2012; Kumaraswamy \& Chan, 1998; Sambasivan \& Soon, 2007; Assaf \& Al-Hejji, 2006; Gündüz et al., 2012; Kumaraswamy \& Chan, 1998; Muhwezi et al., 2014; Sambasivan \& Soon, 2007). Besides, those factors which are related to contractor are also empirically examined by different researchers (e.g. Aibinu \& Odeyinka, 2006; Assaf \& Al-Hejji, 2006; Doloi et al., 2012; Faridi \& El-Sayegh, 2006; Gündüz et al., 2012; Sambasivan \& Soon, 2007). 


\section{Variable Description}

\subsection{Mismanagement in Contracts}

This study has considered "mismanagement in contracts" as a dependent variable of the study. It indicates overall poor performance in the construction either through client, consultant or contractor related factors. Mismanagement in contracts has several dimensions to expresses. First, some researchers considered overall mismanagement in contracts as the first item among five (Ahmed et al., 2002; Chester \& Hendrickson, 2005). The second one is entitled poor deliver of the contract (Aibinu \& Jagboro, 2002), which reflects a major breakthrough in overall project. Third dimension of mismanagement in contract is measured through high cost of contract delivery (Kaming et al., 1997) indicating material and labor related financial losses. Fourth item is represented through customer satisfaction (Kärnä, 2004). Fifth item reflects the effect on future contracts (Dunn \& Spatt, 2005). All these items are measured through five-point Likert scale, ranging from 1 to 5, as described under next section.

\subsection{Client Related Factors of Mismanagement in Contracts}

Literature context on present topic has provided list of factors, responsible for the mismanagement in contracts. This study has considered client related factors like lack of involvement, lack of strategy, absence of executive direction, failure to compile required documents, poor planning, lack of change management, poor risk management, delay in decision making, interference of owner, financial issues, late payments, poor communication, difficulty in getting work permit, mistakes in documents, and lack of management expertise as core items, measured on Likert scale of five. Some of the significant studies which have considered these factors are conducted in the literature (Aibinu \& Odeyinka, 2006; Doloi et al., 2012; Farooqui \& Ahmed, 2008; Odeh \& Battaineh, 2002; Salleh, 2009).

\subsection{Consultant Related Factors of Mismanagement in Contracts}

Those factors which are causing mismanagement in construction projects from the context of consultants are inexperienced consultant, weak executive performance, poor planning, poor design, late of instruction from architects, poor contract management, inaccurate bill of quantities, poor quality assurance, lack of coordination, lack of strategies for project success. Respondents are instructed to provide their valuable feedback for all of these factors with their significance in mismanagement of construction projects. Theoretical support for these factors covers the contribution by (Gündüz et al., 2012; Kumaraswamy \& Chan, 1998; Odeh \& Battaineh, 2002; Sambasivan \& Soon, 2007).

\subsection{Contractor Related Factors of Mismanagement in Contracts}

The third factor for the mismanagement in contract is related to the contractors. These are under the title of inexperience contractor, poor coordination with the related parties, poor qualification of technical staff, inadequate involvement of contractor, poor planning and scheduling of the project, slow mobilization of subcontractor, late or improper preparation of contract submission, difficulty in financing project, delay in progress of payments, inadequate supervision of site and inspection, conflict between contractors with other parties, poor site management, poor construction methods, construction mistake and defective work, weak leadership performance, lack of communication between parties, and problems with subcontractors. These items are examined in various studies (Assaf \& Al-Hejji, 2006; Aziz \& Abdel-Hakam, 2016; Bekker \& Mashaba, 2018; Hwang, Zhao, \& Tan, 2015; Sambasivan et al., 2017; Sekar et al., 2018; Shrivas \& Singla, 2018; Van et al., 2015). Like previous two factors (client and consultant), all these items are also presented on the similar Likert scale.

\section{Methods and Sample of the Study}

This study is based on quantitative research. For this purpose, research design has followed the approach of primary data collection through questionnaire approach. Three major independent variables are client 
related factors, contractor related factors, and consultant related factors. Main dependent variable is mismanagement is construction projects. A questionnaire is developed considering all variables through various items from relevant literature. Demographic factors are also added in the questionnaire to describe the respondent's characteristics, based on age, gender, work experience, job title and job position. At first 165 questionnaires were physically distributed to those individuals who are fit as targeted respondents. For this purpose, guideline is availed from the literature sources with the primary focus on those who are related to public and private sector construction projects. After two weeks 148 questionnaires were received back. Detailed review of the questionnaire indicates some respondents have not provided their meaningful responses on five points Likert scale (strongly disagree=1, strongly agree=5). Therefore, questionnaires with the missing responses were ignored. A final sample of 137 questionnaires are found to be fit for the demographic and empirical analysis.

\section{Results and Discussion}

Table 1 reflects the findings for demographic factors. As per gender distribution, male respondents are 114 covering a percentage share of 83.2 and female of 23 . For the distribution of age, 79 respondents belong to age range of 21-30 years, 42 belongs to 31-40 years, 12 from 41-50 years and 4 respondents are 50 are above. As per job title, 12 respondents are the project manager, 8 are architect, 61 are engineer covering a sample portion of 44.5 percent. While 33 are the quantity surveyor and 23 belongs to other categories. As per job experience, 69 respondents have an experience of 1-5 years, 44 have 6-10 years, and 10 having a work-related expertise of 11-15 years. Meanwhile 6 are those which have work experience of 16-20 years in the field of contract and project management. While only 8 have a work experience of above 20 years. As per distribution of job position, 17 belong to non-executives, 79 have their executive position, 28 have managerial post and 13 have some other job position in their relevant fields of work.

Table 1

Demographic Details

\begin{tabular}{|c|c|c|c|c|c|}
\hline & & Frequency & Percent & Valid Percent & Cumulative Percent \\
\hline \multirow{4}{*}{ Gender } & Male & 114 & 83.2 & 83.2 & 83.2 \\
\hline & Female & 23 & 16.8 & 16.8 & 100.0 \\
\hline & Total & 137 & 100.0 & 100.0 & \\
\hline & & Frequency & Percent & Valid Percent & Cumulative Percent \\
\hline \multirow{6}{*}{ Age } & 21-30 years old & 79 & 57.7 & 57.7 & 57.7 \\
\hline & $31-40$ years old & 42 & 30.7 & 30.7 & 88.3 \\
\hline & $41-50$ years old & 12 & 8.8 & 8.8 & 97.1 \\
\hline & 50 and above & 4 & 2.9 & 2.9 & 100.0 \\
\hline & Total & 137 & 100.0 & 100.0 & \\
\hline & & Frequency & Percent & Valid Percent & Cumulative Percent \\
\hline \multirow{7}{*}{ Job title } & Project Manager & 12 & 8.8 & 8.8 & 8.8 \\
\hline & Architect & 8 & 5.8 & 5.8 & 14.6 \\
\hline & Engineer & 61 & 44.5 & 44.5 & 59.1 \\
\hline & Quantity Surveyor & 33 & 24.1 & 24.1 & 83.2 \\
\hline & Others & 23 & 16.8 & 16.8 & 100.0 \\
\hline & Total & 137 & 100.0 & 100.0 & \\
\hline & & Frequency & Percent & Valid Percent & Cumulative Percent \\
\hline \multirow{7}{*}{ Experience } & $1-5$ years & 69 & 50.4 & 50.4 & 50.4 \\
\hline & $6-10$ years & 44 & 32.1 & 32.1 & 82.5 \\
\hline & $11-15$ years & 10 & 7.3 & 7.3 & 89.8 \\
\hline & $16-20$ years & 6 & 4.4 & 4.4 & 94.2 \\
\hline & more than 20 years & 8 & 5.8 & 5.8 & 100.0 \\
\hline & Total & 137 & 100.0 & 100.0 & \\
\hline & & Frequency & Percent & Valid Percent & Cumulative Percent \\
\hline \multirow{5}{*}{ Job position } & Non-executive & 17 & 12.4 & 12.4 & 12.4 \\
\hline & Executive & 79 & 57.7 & 57.7 & 70.1 \\
\hline & Managerial & 28 & 20.4 & 20.4 & 90.5 \\
\hline & Others & 13 & 9.5 & 9.5 & 100.0 \\
\hline & Total & 137 & 100.0 & 100.0 & \\
\hline
\end{tabular}


Table 2 reflects the effect of client related factors on mismanagement in contract. Overall fifteen items have been extracted from existing literature to reflect the client related factors of mismanagement in contract. The factor of "absence of executive direction" or CLF3 indicates a significant direct effect on overall mismanagement in contract, high cost of contract delivery and customer satisfaction. It means that more absence of executive direction from the client, more mismanagement, high cost and negative customer satisfaction will be experienced. The factor of lack of strategy from the client or CLRF2 indicates a negative influence on customer satisfaction and future contracts for the business. Poor planning or CLRF5 explains a significant influence on poor delivery and low customer satisfaction. Delay in decision making indicates overall mismanagement, poor delivery of contract, high cost of contract delivery and negative influence on future contacts. Financial issues from the clients are significantly leading to overall mismanagement, poor delivery of contract high cost of contract delivery, and negative influence on customer satisfaction. Factor of late payment settlements explains direct influence on overall mismanagement of contract, high cost, and customer satisfaction. To face difficulty in getting work permit from the client by the contractor indicates the fact that it is directly and significantly affecting the cost of contract, contract delivery and customer satisfaction. The factor lack of management expertise or CLRF15 points out direct influence on overall mismanagement cost of contract delivery and adverse effect on future contracts as well. All client related factors specify an explanatory power of 52.1 percent in mismanagement of contract, followed by 49.5 percent in poor contact delivery.

Table 2

Mismanagement in Contract (Client Related Factors)

\begin{tabular}{|c|c|c|c|c|c|}
\hline VARIABLES & $\begin{array}{c}\text { (1) } \\
\text { Overall Mis- } \\
\text { management } \\
\text { in Contract }\end{array}$ & $\begin{array}{c}(2) \\
\text { Poor } \\
\text { delivery of } \\
\text { Contract } \\
\end{array}$ & $\begin{array}{l}\text { (3) } \\
\text { High Cost of } \\
\text { Contract De- } \\
\text { livery }\end{array}$ & $\begin{array}{c}(4) \\
\text { Customer } \\
\text { Satisfaction }\end{array}$ & $\begin{array}{c}\text { (5) } \\
\text { Effect on } \\
\text { future } \\
\text { contracts }\end{array}$ \\
\hline Lack of Involvement:CLRF1 & $\begin{array}{c}-0.0170 \\
(0.0790)\end{array}$ & $\begin{array}{c}0.0715 \\
(0.0886)\end{array}$ & $\begin{array}{l}0.0877 \\
(0.101)\end{array}$ & $\begin{array}{c}-0.0930 \\
(0.114)\end{array}$ & $\begin{array}{c}0.121 \\
(0.0981)\end{array}$ \\
\hline Lack of Strategy:CLRF2 & $\begin{array}{c}0.142 \\
(0.105)\end{array}$ & $\begin{array}{c}0.161 \\
(0.145)\end{array}$ & $\begin{array}{l}-0.224 \\
(0.148)\end{array}$ & $\begin{array}{c}-0.440 * * * \\
(0.158)\end{array}$ & $\begin{array}{c}-0.415^{* * *} \\
(0.154)\end{array}$ \\
\hline Absence of Executive direction:CLRF3 & $\begin{array}{c}0.275^{* *} \\
(0.107)\end{array}$ & $\begin{array}{l}0.0255 \\
(0.122)\end{array}$ & $\begin{array}{c}0.267 * * \\
(0.116)\end{array}$ & $\begin{array}{c}-0.420 * * * \\
(0.143)\end{array}$ & $\begin{array}{r}-0.0403 \\
(0.150)\end{array}$ \\
\hline Failure to compile required documents:CLRF4 & $\begin{array}{c}-0.374 * * * \\
(0.0819)\end{array}$ & $\begin{array}{l}-0.0542 \\
(0.130)\end{array}$ & $\begin{array}{l}-0.0816 \\
(0.0826)\end{array}$ & $\begin{array}{c}0.0183 \\
(0.0943)\end{array}$ & $\begin{array}{c}0.0893 \\
(0.0958)\end{array}$ \\
\hline Poor Planning: CLRF5 & $\begin{array}{c}-0.113 \\
(0.0900)\end{array}$ & $\begin{array}{l}0.222^{*} \\
(0.117)\end{array}$ & $\begin{array}{l}-0.0900 \\
(0.0929)\end{array}$ & $\begin{array}{l}-0.155^{*} \\
(0.0887)\end{array}$ & $\begin{array}{c}0.00959 \\
(0.101)\end{array}$ \\
\hline Lack of managing changes: CLRF6 & $\begin{array}{c}-0.0815 \\
(0.148)\end{array}$ & $\begin{array}{c}0.154 \\
(0.159)\end{array}$ & $\begin{array}{c}-0.0410 \\
(0.161)\end{array}$ & $\begin{array}{l}-0.188 \\
(0.158)\end{array}$ & $\begin{array}{l}-0.247 \\
(0.173)\end{array}$ \\
\hline Poor Risk Management: CLRF7 & $\begin{array}{l}0.0137 \\
(0.129)\end{array}$ & $\begin{array}{l}-0.0106 \\
(0.153)\end{array}$ & $\begin{array}{r}-0.0705 \\
(0.122)\end{array}$ & $\begin{array}{c}0.145 \\
(0.112)\end{array}$ & $\begin{array}{l}0.236^{*} \\
(0.121)\end{array}$ \\
\hline Delay in decision making: CLRF8 & $\begin{array}{c}0.233 * * * \\
(0.0845)\end{array}$ & $\begin{array}{c}0.579 * * * \\
(0.0956)\end{array}$ & $\begin{array}{c}0.409 * * * \\
(0.0956)\end{array}$ & $\begin{array}{l}-0.0811 \\
(0.0937)\end{array}$ & $\begin{array}{l}-0.160 * \\
(0.0884)\end{array}$ \\
\hline Interference of Owner: CLRF9 & $\begin{array}{l}-0.154 \\
(0.172)\end{array}$ & $\begin{array}{l}-0.0470 \\
(0.181)\end{array}$ & $\begin{array}{l}-0.147 \\
(0.194)\end{array}$ & $\begin{array}{c}-0.00307 \\
(0.184)\end{array}$ & $\begin{array}{c}0.698 \\
(0.914)\end{array}$ \\
\hline Financial issues: CLRF10 & $\begin{array}{c}0.296 * * * \\
(0.0861)\end{array}$ & $\begin{array}{c}0.325^{* * *} \\
(0.0968)\end{array}$ & $\begin{array}{c}0.265^{* * *} \\
(0.100)\end{array}$ & $\begin{array}{c}-0.187 * * \\
(0.0940)\end{array}$ & $\begin{array}{c}0.119 \\
(0.101)\end{array}$ \\
\hline Late payment settlements: CLRF11 & $\begin{array}{l}0.194 * * \\
(0.0890)\end{array}$ & $\begin{array}{c}-0.0721 \\
(0.121)\end{array}$ & $\begin{array}{l}0.171^{*} \\
(0.102)\end{array}$ & $\begin{array}{c}0.174^{*} \\
(0.0948)\end{array}$ & $\begin{array}{c}0.263 * * \\
(0.101)\end{array}$ \\
\hline Poor communication CLRF12 & $\begin{array}{l}-0.176^{*} \\
(0.0992)\end{array}$ & $\begin{array}{l}-0.174 \\
(0.109)\end{array}$ & $\begin{array}{l}-0.177 \\
(0.107)\end{array}$ & $\begin{array}{l}-0.134 \\
(0.112)\end{array}$ & $\begin{array}{r}-0.0808 \\
(0.112)\end{array}$ \\
\hline Difficulty in getting work permit: CLRF13 & $\begin{array}{c}-0.0520 \\
(0.100)\end{array}$ & $\begin{array}{c}0.330 * * * \\
(0.116)\end{array}$ & $\begin{array}{c}0.346 * * * \\
(0.114)\end{array}$ & $\begin{array}{c}-0.338^{* * *} \\
(0.113)\end{array}$ & $\begin{array}{c}0.160 \\
(0.109)\end{array}$ \\
\hline Mistakes in documents: CLRF14 & $\begin{array}{c}0.192 \\
(0.129)\end{array}$ & $\begin{array}{l}-0.146 \\
(0.192)\end{array}$ & $\begin{array}{r}-0.0306 \\
(0.140)\end{array}$ & $\begin{array}{l}0.0301 \\
(0.142)\end{array}$ & $\begin{array}{l}-0.110 \\
(0.147)\end{array}$ \\
\hline Lack of management expertise: CLRF15 & $\begin{array}{c}0.461 * * * \\
(0.0998)\end{array}$ & $\begin{array}{c}0.152 \\
(0.130)\end{array}$ & $\begin{array}{c}0.266^{* *} \\
(0.128)\end{array}$ & $\begin{array}{c}0.132 \\
(0.102)\end{array}$ & $\begin{array}{c}-0.315^{* * *} \\
(0.110)\end{array}$ \\
\hline Constant & $\begin{array}{c}3.956^{* * * *} \\
(0.446)\end{array}$ & $\begin{array}{l}1.056^{* *} \\
(0.456)\end{array}$ & $\begin{array}{c}2.135^{* * * *} \\
(0.537)\end{array}$ & $\begin{array}{c}1.391 * * * \\
(0.457)\end{array}$ & $\begin{array}{c}-0.134 \\
(0.594)\end{array}$ \\
\hline Observations & 137 & 137 & 137 & 137 & 137 \\
\hline R-squared & 0.521 & 0.495 & 0.463 & 0.474 & 0.530 \\
\hline
\end{tabular}

Robust standard errors in parentheses

$* * * \mathrm{p}<0.01, * * \mathrm{p}<0.05, * \mathrm{p}<0.1$ 
Table 3 reflects consultant related factors of mismanagement in the contact. First factor "inexperienced consultant" or CNRLF1 explains its direct influence on mismanagement of contract, poor delivery, high cost and low customer satisfaction. Poor planning from consultant expresses directly impact on poor contract delivery, and high cost factors. While low customer experienced is also observed through poor planning. Poor design from consultant indicates overall mismanagement in contract. The factor of late instruction from the clients defines its significant and direct influence on all the factors of contract mismanagement. While poor contract management by the consultant is also responsible for contract mismanagement, and high cost of contract delivery and low customer satisfaction. In addition, factor of poorquality assurance shows a direct influence on mismanagement of contract, high cost, poor delivery and customer satisfaction. The title ofCNRLF10 or lack of strategic for project success explains higher cost of contract delivery, poor delivery, and customer satisfaction. Table 4 predicts the impact of contractor related factors on mismanagement of contracts. It is observed that inexperienced contracts leads to the overall mismanagement with the coefficient of .340 and standard error of .128. In the meantime, future contracts are negatively and significant affected by inexperienced contractor.

\section{Table 4}

Consultant Related Factors for contract Mismanagement

\begin{tabular}{|c|c|c|c|c|c|}
\hline VARIABLES & $\begin{array}{c}(1) \\
\text { Overall Mis- } \\
\text { management } \\
\text { in Contract }\end{array}$ & $\begin{array}{c}\text { (2) } \\
\text { Poor } \\
\text { delivery of } \\
\text { Contract } \\
\end{array}$ & $\begin{array}{c}(3) \\
\text { High Cost of } \\
\text { Contract De- } \\
\text { livery }\end{array}$ & $\begin{array}{c}(4) \\
\text { Customer } \\
\text { Satisfaction }\end{array}$ & $\begin{array}{c}\text { (5) } \\
\text { Effect on fu- } \\
\text { ture } \\
\text { contracts }\end{array}$ \\
\hline Inexperienced consultant: CNRLF1 & $\begin{array}{l}0.198^{*} \\
(0.107)\end{array}$ & $\begin{array}{c}0.310^{* *} \\
(0.128)\end{array}$ & $\begin{array}{c}0.533 * * * \\
(0.119)\end{array}$ & $\begin{array}{c}-0.411 * * * \\
(0.108)\end{array}$ & $\begin{array}{l}0.0847 \\
(0.118)\end{array}$ \\
\hline Weak executive performance: CNRLF2 & $\begin{array}{c}0.121 \\
(0.122)\end{array}$ & $\begin{array}{c}-0.00702 \\
(0.137)\end{array}$ & $\begin{array}{c}-0.285^{* *} \\
(0.114)\end{array}$ & $\begin{array}{c}-0.0740 \\
(0.117)\end{array}$ & $\begin{array}{l}-0.177 \\
(0.150)\end{array}$ \\
\hline Poor planning CNRLF3 & $\begin{array}{c}-0.0785 \\
(0.115)\end{array}$ & $\begin{array}{c}0.437 * * * \\
(0.136)\end{array}$ & $\begin{array}{c}0.383 * * * \\
(0.140)\end{array}$ & $\begin{array}{c}-0.368 * * \\
(0.156)\end{array}$ & $\begin{array}{c}-0.0152 \\
(0.161)\end{array}$ \\
\hline Poor design: CNRLF4 & $\begin{array}{c}-0.300 * * * \\
(0.0873)\end{array}$ & $\begin{array}{l}-0.159 \\
(0.133)\end{array}$ & $\begin{array}{l}0.0101 \\
(0.122)\end{array}$ & $\begin{array}{l}-0.171 \\
(0.137)\end{array}$ & $\begin{array}{c}-0.374 \\
(0.947)\end{array}$ \\
\hline Late of instruction from architects CNRLF5 & $\begin{array}{l}0.192 * * \\
(0.0856)\end{array}$ & $\begin{array}{c}0.409 * * * \\
(0.0993)\end{array}$ & $\begin{array}{c}0.328 * * * \\
(0.107)\end{array}$ & $\begin{array}{c}-0.591 * * * \\
(0.124)\end{array}$ & $\begin{array}{c}0.872 * * * \\
(0.140)\end{array}$ \\
\hline Poor Contract Management CNRLF6 & $\begin{array}{c}0.357 * * * \\
(0.0900)\end{array}$ & $\begin{array}{c}0.00824 \\
(0.115)\end{array}$ & $\begin{array}{c}0.304^{* *} \\
(0.126)\end{array}$ & $\begin{array}{c}-0.287 * * \\
(0.137)\end{array}$ & $\begin{array}{l}0.0419 \\
(0.106)\end{array}$ \\
\hline Inaccurate bill of quantities: CNRLF7 & $\begin{array}{c}0.0137 \\
(0.0943)\end{array}$ & $\begin{array}{c}0.213 \\
(0.137)\end{array}$ & $\begin{array}{c}0.303^{* *} \\
(0.117)\end{array}$ & $\begin{array}{c}-0.0536 \\
(0.110)\end{array}$ & $\begin{array}{l}0.0171 \\
(0.126)\end{array}$ \\
\hline Poor quality assurance: CNRLF8 & $\begin{array}{c}0.441 * * * \\
(0.131)\end{array}$ & $\begin{array}{c}0.221^{* *} \\
(0.108)\end{array}$ & $\begin{array}{c}0.308 * * * \\
(0.0794)\end{array}$ & $\begin{array}{l}-0.211 * * \\
(0.0915)\end{array}$ & $\begin{array}{l}-0.102 \\
(0.127)\end{array}$ \\
\hline Lack of coordination: CNRLF9 & $\begin{array}{l}-0.160 \\
(0.134)\end{array}$ & $\begin{array}{c}-0.0344 \\
(0.131)\end{array}$ & $\begin{array}{l}0.0831 \\
(0.136)\end{array}$ & $\begin{array}{l}0.0482 \\
(0.118)\end{array}$ & $\begin{array}{c}0.135 \\
(0.103)\end{array}$ \\
\hline Lack of strategies for project success :CNRLF10 & $\begin{array}{l}0.0722 \\
(0.106)\end{array}$ & $\begin{array}{c}0.438 * * * \\
(0.122)\end{array}$ & $\begin{array}{c}0.503 * * * \\
(0.107)\end{array}$ & $\begin{array}{l}0.190^{*} \\
(0.108)\end{array}$ & $\begin{array}{c}0.116 \\
(0.114)\end{array}$ \\
\hline Constant & $\begin{array}{c}2.822 * * * \\
(0.628)\end{array}$ & $\begin{array}{c}1.546^{* * * *} \\
(0.487)\end{array}$ & $\begin{array}{c}1.786^{* * *} \\
(0.444)\end{array}$ & $\begin{array}{c}1.417 * * * \\
(0.403)\end{array}$ & $\begin{array}{c}1.252 * * * \\
(0.381)\end{array}$ \\
\hline Observations & 137 & 137 & 137 & 137 & 137 \\
\hline R-squared & 0.322 & 0.286 & 0.363 & 0.375 & 0.416 \\
\hline
\end{tabular}

Robust standard errors in parentheses

$* * * \mathrm{p}<0.01, * * \mathrm{p}<0.05, * \mathrm{p}<0.1$

Higher cost of delivery is observed through poor qualification of contractor. The factor of "poor planning and scheduling of the project" indicates direct influence on all the dimensions of contract mismanagement, except for the customer satisfaction and future contracts which are negatively and significantly affected. Through late preparation of contractor submission, direct $\&$ significant influence is observed on all the items of mismanagement in contract. It is observed that if the contractor is not supervising the site, its impact on mismanagement of contract and poor delivery of contract is direct and significant. While the factor of conflict between the contractor and other parties are adversely affecting the customer satisfaction with the coefficient of -.344 . Poor construction methods by the contractor is also another factor, responsible for mismanagement of the contract. It is also observed that CNTRF13 leading to the high cost of contract, low customer satisfaction and negative effect on future contracts as well. Besides, 
construction mistakes and defective work expresses poor delivery high cost, and low customer satisfaction. The factor of weak leadership performance defines its direct influence on all the factor of contact mismanagement except future contracts. Besides, lack of communication between the parties indicates its significant impact on poor delivery of contract, and higher cost. The last item of contractor related factors "problem with the subcontractors or CNTRF17" points out significant influence on poor contract delivery.

\section{Table 5}

Contractor Related Factors for contract Mismanagement

\begin{tabular}{|c|c|c|c|c|c|}
\hline VARIABLES & $\begin{array}{c}\text { (1) } \\
\text { Overall } \\
\text { Misman- } \\
\text { agement in } \\
\text { Contract } \\
\end{array}$ & $\begin{array}{l}\text { (2) } \\
\text { Poor deliv- } \\
\text { ery of Con- } \\
\text { tract }\end{array}$ & $\begin{array}{c}\text { (3) } \\
\text { High Cost } \\
\text { of Contract } \\
\text { Delivery }\end{array}$ & $\begin{array}{c}\text { (4) } \\
\text { Customer } \\
\text { Satisfaction }\end{array}$ & $\begin{array}{c}\text { (5) } \\
\text { Effect on } \\
\text { future } \\
\text { contracts }\end{array}$ \\
\hline Inexperience contractor : CNTRF1 & $\begin{array}{c}0.340 * * * \\
(0.128)\end{array}$ & $\begin{array}{c}-0.0407 \\
(0.0950)\end{array}$ & $\begin{array}{l}0.0294 \\
(0.105)\end{array}$ & $\begin{array}{c}0.121 \\
(0.121)\end{array}$ & $\begin{array}{l}-0.206^{*} \\
(0.116)\end{array}$ \\
\hline Poor coordination with related parties :CNTRF2 & $\begin{array}{c}0.238 \\
(0.222)\end{array}$ & $\begin{array}{c}-0.180 \\
(0.146)\end{array}$ & $\begin{array}{c}0.444 * * \\
(0.212)\end{array}$ & $\begin{array}{c}-0.00800 \\
(0.209)\end{array}$ & $\begin{array}{c}-0.0950 \\
(0.217)\end{array}$ \\
\hline Poor qualification of the technical staff : CNTRF3 & $\begin{array}{l}0.0514 \\
(0.121)\end{array}$ & $\begin{array}{c}0.473 \\
(0.903)\end{array}$ & $\begin{array}{c}0.119 \\
(0.140)\end{array}$ & $\begin{array}{c}0.112 \\
(0.142)\end{array}$ & $\begin{array}{c}0.291 \\
(0.752)\end{array}$ \\
\hline Inadequate involvement of contractor: CNTRF4 & $\begin{array}{r}-0.0223 \\
(0.173)\end{array}$ & $\begin{array}{r}-0.0415 \\
(0.142)\end{array}$ & $\begin{array}{c}0.120 \\
(0.186)\end{array}$ & $\begin{array}{c}-0.296^{*} \\
(0.169)\end{array}$ & $\begin{array}{c}0.109 \\
(0.198)\end{array}$ \\
\hline $\begin{array}{l}\text { Poor planning and scheduling of the project } \\
\text { :CNTRF5 }\end{array}$ & $\begin{array}{c}0.387 * * * \\
(0.127)\end{array}$ & $\begin{array}{c}0.835 * * * \\
(0.117)\end{array}$ & $\begin{array}{c}0.485 * * * \\
(0.125)\end{array}$ & $\begin{array}{c}-0.631 * * * \\
(0.150)\end{array}$ & $\begin{array}{c}-0.368 * * \\
(0.167)\end{array}$ \\
\hline Slow mobilization of subcontractor :CNTRF6 & $\begin{array}{c}-0.0661 \\
(0.0976)\end{array}$ & $\begin{array}{c}0.136 \\
(0.7671)\end{array}$ & $\begin{array}{c}-0.0329 \\
(0.0871)\end{array}$ & $\begin{array}{c}-0.326^{* * *} \\
(0.110)\end{array}$ & $\begin{array}{c}-0.617 * * * \\
(0.102)\end{array}$ \\
\hline $\begin{array}{l}\text { Late or improper preparation of contract submis- } \\
\text { sion:CNTRF7 }\end{array}$ & $\begin{array}{l}0.233 * * * \\
(0.0739)\end{array}$ & $\begin{array}{l}0.253 * * * \\
(0.0912)\end{array}$ & $\begin{array}{c}0.375 * * * \\
(0.117)\end{array}$ & $\begin{array}{c}0.362 * * * \\
(0.125)\end{array}$ & $\begin{array}{c}0.661 * * * \\
(0.108)\end{array}$ \\
\hline Difficulty in financing project:CNTRF8 & $\begin{array}{c}0.174 \\
(0.182)\end{array}$ & $\begin{array}{c}0.0337 \\
(0.125)\end{array}$ & $\begin{array}{c}0.395 \\
(0.856)\end{array}$ & $\begin{array}{c}0.268 \\
(0.167)\end{array}$ & $\begin{array}{c}0.167 \\
(0.137)\end{array}$ \\
\hline Delay in progress of payments:CNTRF9 & $\begin{array}{l}0.154 \\
(0.101)\end{array}$ & $\begin{array}{l}0.0324 \\
(0.0807)\end{array}$ & $\begin{array}{c}0.211 \\
(0.511)\end{array}$ & $\begin{array}{l}0.290 \\
(0.619)\end{array}$ & $\begin{array}{r}-0.0369 \\
(0.117)\end{array}$ \\
\hline $\begin{array}{l}\text { Inadequate site supervision and inspec- } \\
\text { tion:CNTRF10 }\end{array}$ & $\begin{array}{l}0.214^{*} \\
(0.128)\end{array}$ & $0.309 * * *$ & $\begin{array}{r}-0.0340 \\
(0.155)\end{array}$ & -0.159 & $\begin{array}{l}-0.0259 \\
(0.107)\end{array}$ \\
\hline $\begin{array}{l}\text { Conflict between contractors with other parties } \\
\text { :CNTRF } 11\end{array}$ & $\begin{array}{l}-0.174 \\
(0.163)\end{array}$ & 0.233 & 0.0331 & $-0.344 * *$ & $\begin{array}{l}0.0730 \\
(0.183)\end{array}$ \\
\hline Poor site management CNTRF12 & $\begin{array}{l}-0.175 \\
(0.150)\end{array}$ & $\begin{array}{c}-0.00251 \\
(0.109)\end{array}$ & $\begin{array}{l}-0.236^{*} \\
(0.132)\end{array}$ & $\begin{array}{l}0.0601 \\
(0.125)\end{array}$ & $\begin{array}{c}0.256^{* *} \\
(0.127)\end{array}$ \\
\hline Poor construction methods : CNTRF13 & $\begin{array}{l}0.262^{*} \\
(0.149)\end{array}$ & $\begin{array}{c}-0.143 \\
(0.124)\end{array}$ & $\begin{array}{c}0.416 * * * \\
(0.141)\end{array}$ & $\begin{array}{c}-0.740 * * * \\
(0.145)\end{array}$ & $\begin{array}{c}-0.660 * * * \\
(0.167)\end{array}$ \\
\hline $\begin{array}{l}\text { Construction mistakes and defective } \\
\text { work:CNTRF14 }\end{array}$ & $\begin{array}{c}-0.132 \\
(0.0998)\end{array}$ & $\begin{array}{l}0.178 * * \\
(0.0885)\end{array}$ & $\begin{array}{c}-0.333 * * * \\
(0.0916)\end{array}$ & $-0.339 * * *$ & $\begin{array}{l}-0.117 \\
(0.128)\end{array}$ \\
\hline Weak leadership performance:CNTRF15 & $\begin{array}{c}-0.371 * * * \\
(0.138)\end{array}$ & $\begin{array}{l}0.404 * * * \\
(0.142)\end{array}$ & $\begin{array}{l}0.575 * * * \\
(0.121)\end{array}$ & $\begin{array}{l}0.614 * * * \\
(0.164)\end{array}$ & $\begin{array}{c}0.220 \\
(0.171)\end{array}$ \\
\hline Lack of communication between parties:CNTRF16 & $\begin{array}{l}0.286 * * \\
(0.134)\end{array}$ & $\begin{array}{c}0.478 * * * \\
(0.0956)\end{array}$ & $\begin{array}{l}0.383 * * * \\
(0.131)\end{array}$ & $\begin{array}{c}0.169 \\
(0.105)\end{array}$ & $\begin{array}{l}-0.0440 \\
(0.105)\end{array}$ \\
\hline Problems with subcontractors:CNTRF17 & $\begin{array}{l}0.0256 \\
(0.206)\end{array}$ & $\begin{array}{c}0.523 * * * \\
(0.147)\end{array}$ & $\begin{array}{l}0.0747 \\
(0.176)\end{array}$ & $\begin{array}{c}-0.0323 \\
(0.180)\end{array}$ & $\begin{array}{l}0.0501 \\
(0.161)\end{array}$ \\
\hline Constant & $\begin{array}{c}2.988 * * * \\
(0.441)\end{array}$ & $\begin{array}{c}0.674 \\
(0.490)\end{array}$ & $\begin{array}{c}1.801 * * * \\
(0.561)\end{array}$ & $\begin{array}{c}0.868 \\
(0.610)\end{array}$ & $\begin{array}{c}0.115 \\
(0.664)\end{array}$ \\
\hline Observations & 137 & 137 & 137 & 137 & 137 \\
\hline R-squared & 0.446 & 0.704 & 0.587 & 0.506 & 0.518 \\
\hline
\end{tabular}




\section{Conclusion and Future Recommendations}

This study has significantly addressed the issue of mismanagement of public and private contracts in the region of Indonesia. Various factors have been presented in existing literature covering the title of "factors affecting the poor project/contract delivery". In depth review of present studies has revealed that factors related to the client, consultant and contractor are playing their crucial role for the delay or poor performance of contracts. It is observed that lack of strategy, failure to compile the documentary requirements, poor planning, delay in decision making, financial issues, late payments, difficulty in getting work permits and lack of management expertise are core issues, creating mismanagement in public and private contracts. In consultant related factors, role of inexperienced consultant, poor planning, late of instructions from architects, poor contract management, and poor-quality assurance were considered as key determinants of mismanagement in contracts. While contractor related factors like poor planning and scheduling, late or improper submission of contract, inadequate site supervision and inspection, poor construction methods, weak leadership, and lack of communication between the parties were key indicators of mismanagement in contracts. Based on the study findings, both parties (client and contractor) are highly recommended to consider the following suggestions. At first, delay and poor delivery of the projects can be rethinking if the problems are truly examined, reviewed, and proper plans are developed. Second, those factors which are related to the clients need serious attention during the whole life of the project. Necessary management expertise is highly required to avoid any type of financial or no-financial losses during contract in both public and private sector. Third, issues related to the contractors also need serious attention and highly areas of the study should immediately be addressed by the relevant parties. Contractors with inadequate experience and poor planning issues should not assigned any type of project, until they provide some documentary evidence for their efficient work performance in the past. At fourth, selection of consultant is known as significant decision before starting a project. In this regard, those factors which are related to the consultants like poor planning, poor designing, late of instruction from architects and poor contract management need significant attention. Besides, this study has performed a significant contribution, hence highly recommended in the field of contracts and project management too. Future studies can be conducted through addition of more factors responsible for the poor contract management related to material, equipment and slow decision making.

\section{References}

Ahmed, S. M., Azhar, S., Castillo, M., \& Kappagantula, P. (2002). Construction delays in Florida: An empirical study. Final report. Department of Community Affairs, Florida, US.

Aibinu, A., \& Jagboro, G. (2002). The effects of construction delays on project delivery in Nigerian construction industry. International Journal of project management, 20(8), 593-599.

Aibinu, A. A., \& Odeyinka, H. A. (2006). Construction delays and their causative factors in Nigeria. Journal of construction engineering and management, 132(7), 667-677.

Assaf, S. A., \& Al-Hejji, S. (2006). Causes of delay in large construction projects. International Journal of project management, 24(4), 349-357.

Assaf, S. A., Al-Khalil, M., \& Al-Hazmi, M. (1995). Causes of delay in large building construction projects. Journal of management in engineering, 11(2), 45-50.

Aziz, R. F., \& Abdel-Hakam, A. A. (2016). Exploring delay causes of road construction projects in Egypt. Alexandria Engineering Journal, 55(2), 1515-1539.

Bekker, M. C., \& Mashaba, J. (2018). A critical review of agricultural related construction project failures at the Department of Agricultural, Rural Development and Environmental Affairs (DARDLEA): Mpumalanga. South African Journal of Agricultural Extension, 46(1), 83-91.

Bordoli, D. W., \& Baldwin, A. N. (1998). A methodology for assessing construction project delays. Construction Management \& Economics, 16(3), 327-337.

Chan, D. W., \& Kumaraswamy, M. M. (1996). An evaluation of construction time performance in the building industry. Building and Environment, 31(6), 569-578.

Chan, D. W., \& Kumaraswamy, M. M. (1997). A comparative study of causes of time overruns in Hong Kong construction projects. International Journal of project management, 15(1), 55-63. 
Chester, M., \& Hendrickson, C. (2005). Cost impacts, scheduling impacts, and the claims process during construction. Journal of construction engineering and management, 131(1), 102-107.

Doloi, H., Sawhney, A., Iyer, K., \& Rentala, S. (2012). Analysing factors affecting delays in Indian construction projects. International Journal of project management, 30(4), 479-489.

Dunn, K. B., \& Spatt, C. S. (2005). The effect of refinancing costs and market imperfections on the optimal call strategy and the pricing of debt contracts. Real Estate Economics, 33(4), 595-617.

Faridi, A. S., \& El-Sayegh, S. M. (2006). Significant factors causing delay in the UAE construction industry. Construction Management and Economics, 24(11), 1167-1176.

Farooqui, R., \& Ahmed, S. (2008). Assessment of Pakistani construction industry-current performance and the way forward. Journal for the Advancement of Performance Information \& Value, 1(1).

Frimpong, Y., Oluwoye, J., \& Crawford, L. (2003). Causes of delay and cost overruns in construction of groundwater projects in a developing countries; Ghana as a case study. International Journal of project management, 21(5), 321-326.

Gardiner, P. D. (2005). Project management: A strategic planning approach: Macmillan International Higher Education.

Gündüz, M., Nielsen, Y., \& Özdemir, M. (2012). Quantification of delay factors using the relative importance index method for construction projects in Turkey. Journal of management in engineering, 29(2), 133-139.

Hwang, B.-G., Zhao, X., \& Tan, L. L. G. (2015). Green building projects: Schedule performance, influential factors and solutions. Engineering, Construction and Architectural Management, 22(3), 327-346.

Indonesia Investment. (2018). Public Projects of the Indonesian Government. Retrieved 02-04-2019, 2019, from https://www.indonesia-investments.com/projects/public-projects/item72?

Kaming, P. F., Olomolaiye, P. O., Holt, G. D., \& Harris, F. C. (1997). Factors influencing construction time and cost overruns on high-rise projects in Indonesia. Construction Management \& Economics, 15(1), 83-94.

Kärnä, S. (2004). Analysing customer satisfaction and quality in construction-the case of public and private customers. Nordic journal of surveying and real estate research, 2.

Koushki, P., Al-Rashid, K., \& Kartam, N. (2005). Delays and cost increases in the construction of private residential projects in Kuwait. Construction Management and Economics, 23(3), 285-294.

Kumaraswamy, M. M., \& Chan, D. W. (1998). Contributors to construction delays. Construction Management \& Economics, 16(1), 17-29.

Muhwezi, L., Acai, J., \& Otim, G. (2014). An assessment of the factors causing delays on building construction projects in Uganda. International Journal of Construction Engineering and Management, 3(1), 13-23.

Navon, R. (2005). Automated project performance control of construction projects. Automation in construction, 14(4), 467-476.

Nega, F. (2008). Causes and effects of cost overrun on public building construction projects in Ethiopia. Unpublished doctoral dissertation, Addis Ababa University, Ethiopia.

Odeh, A. M., \& Battaineh, H. T. (2002). Causes of construction delay: traditional contracts. International Journal of project management, 20(1), 67-73.

Ramanathan, C., Narayanan, S., \& Idrus, A. B. (2012). Construction delays causing risks on time and cost-a critical review. Construction Economics and Building, 12(1), 37-57.

Saka, N., \& Ajayi, O. M. (2010). A comparative assessment of incentive scheme between indigenous and multinational construction contractors in Nigeria. Paper presented at the Proceedings of the 26th Annual ARCOM Conference. Leeds, UK.

Salleh, R. (2009). Critical success factors of project management for Brunei construction projects: improving project performance. Queensland University of Technology.

Sambasivan, M., Deepak, T., Salim, A. N., \& Ponniah, V. (2017). Analysis of delays in Tanzanian construction industry: Transaction cost economics (TCE) and structural equation modeling (SEM) approach. Engineering, Construction and Architectural Management, 24(2), 308-325. 
Sambasivan, M., \& Soon, Y. W. (2007). Causes and effects of delays in Malaysian construction industry. International Journal of project management, 25(5), 517-526.

Sekar, G., Viswanathan, K., \& Sambasivan, M. (2018). Effects of Project-Related and OrganizationalRelated Factors on Five Dimensions of Project Performance: A Study Across the Construction Sectors in Malaysia. Engineering Management Journal, 30(4), 247-261.

Shrivas, A., \& Singla, H. K. (2018). Factors Causing Delay in Marine Construction Projects in India. $i$ Manager's Journal on Civil Engineering, 8(3), 12.

Van, L. T., Sang, N. M., \& Viet, N. T. (2015). A conceptual model of delay factors affecting government construction projects. ARPN Journal of Science and Technology, 5(2), 92-100.

Wiguna, I., \& Scott, S. (2005). Analysing the risks affecting construction delay and cost overruns in Indonesian building projects. Paper presented at the Proceedings of the 3rd International Conference on Innovation in Architecture, Engineering and Construction.

Winch, G. M. (2010). Managing construction projects: John Wiley \& Sons.

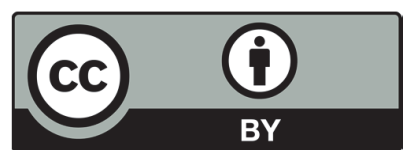

(C) 2019 by the authors; licensee Growing Science, Canada. This is an open access article distributed under the terms and conditions of the Creative Commons Attribution (CCBY) license (http://creativecommons.org/licenses/by/4.0/). 